\title{
Influence of soil tillage system, forecrop and kind of crop residue on spring barley infection by pathogenic fungi
}

\section{Wpływ sposobu uprawy gleby, przedplonu i rodzaju pozostawionej biomasy na porażenie jęczmienia jarego przez grzyby chorobotwórcze}

\author{
Leszek Majchrzak, Zuzanna Sawinska
}

\section{Summary}

Field experiment was conducted in the years 2007-2009 at the Research and Education Center Gorzyń branch Swadzim Poznań University of Life Sciences. The aim of this study was to determine the severity of infection by patogenic fungi on spring barley as an effect by different tillage systems (conventional and direct drilling), forecrop (beet and maize) and kind of crop residue (white mustard, oats, spring vetch, wheat straw and wheat stubble).

Key words: spring barley, diseases infection, forecrop, crop residue, tillage system

\section{Streszczenie}

Badania przeprowadzono w latach 2007-2009, w Zakładzie Doświadczalno-Dydaktycznym Gorzyń, filia Swadzim należącym do Uniwersytetu Przyrodniczego w Poznaniu. Celem ich była ocena stopnia porażenia jęczmienia jarego przez grzyby chorobotwórcze w zależności od sposobu uprawy gleby (tradycyjny i siew bezpośredni), przedplonu (burak i kukurydza) i rodzaju pozostawionej biomasy (gorczyca biała, owies, wyka jara, słoma pszenna, ściernisko po zbiorze pszenicy ozimej).

Słowa kluczowe: jęczmień jary, porażenie chorobami, przedplon, resztki pożniwne, sposób uprawy

Uniwersytet Przyrodniczy w Poznaniu

Katedra Agronomii

Dojazd 11, 60-632 Poznań

leszmaj@up.poznan.pl 


\section{Wstęp / Introduction}

Spośród wszystkich podstawowych gatunków zbóż okres wegetacji jęczmienia jarego jest najkrótszy, mimo to choroby grzybowe wyrządzają duże straty w jego plonach. Jest to spowodowane głównie zwiększaniem areału uprawy tego gatunku w strukturze zasiewów oraz zmianą warunków klimatycznych (Pecio i Danyte 2008), a także stosowaniem uproszczeń w uprawie roli (Parylak 2004). Bardzo często jęczmień jary jest uprawiany na przemian $\mathrm{z}$ pszenicą lub nawet $\mathrm{w}$ monokulturze. Prowadzi to do pogorszenia stanu fitosanitarnego stanowisk, na których uprawia się zboża, wzrostu zachwaszczenia łanu oraz porażenia roślin przez choroby (Wojciechowski 2005), a w konsekwencji do spadku plonu ziarna i pogarszania jego jakości. W takich warunkach dużego znaczenia nabiera nawożenie słomą, czy też biomasą międzyplonów przyoraną w uprawie tradycyjnej, bądź pozostawianą jako mulcz w systemach uprawy uproszczonej lub siewów bezpośrednich (Duer 1996; Kotwica i wsp. 1998). Wzrasta rola międzyplonów jako czynnika poprawiającego bilans substancji organicznej w glebie, ograniczającego wymywanie azotanów do wód gruntowych, zwiększającego aktywność biologiczną i potencjał fitosanitarny gleby oraz chroniącego glebę przed erozją (Dzienia i Boligłowa 1993; Duer 1996; Richards i wsp. 1996).

Stosowane ze względów ekonomicznych, jak i środowiskowych bezorkowe systemy uprawy roli, obok szeregu zalet, mogą prowadzić do negatywnych następstw, do których zaliczyć można zwiększone porażenie roślin chorobami. Spośród chorób powodowanych przez grzyby patogeniczne związane ze środowiskiem glebowym za najgroźniejsze uważa się sprawców chorób podsuszkowych.

Celem przeprowadzonych badań była ocena stopnia porażenia jęczmienia jarego w zależności od sposobu uprawy gleby, przedplonu i rodzaju pozostawionej biomasy.

\section{Materiały i metody / Materials and methods}

W latach 2007-2009 w Katedrze Agronomii Uniwersytetu Przyrodniczego w Poznaniu, Zakładzie Doświadczalno-Dydaktycznym Gorzyń, filia Swadzim, przeprowadzono doświadczenia polowe, mające na celu ocenę wpływu systemu uprawy roli: płużny i siew bezpośredni (siewnik z redlicami talerzowymi firmy Great Plains), przedplonu, którym były buraki pastewne i kukurydza, a także rodzaju pozostawionej biomasy: ściernisko - obiekt kontrolny, gorczyca biała, owies, wyka jara i pozostawiona słoma pszenna w kontekście nasilenia występowania chorób grzybowych na jęczmieniu jarym. Ocenę porażenia roślin przeprowadzono w 3 sezonach wegetacyjnych $\mathrm{w}$ fazie dojrzałości mlecznej jęczmienia jarego (BBCH 71-75) na 100 roślinach losowo pobranych z kombinacji, określając odsetek źdźbeł z objawami porażenia. Nasilenie chorób podsuszkowych wyrażono dodatkowo indeksem porażenia w skali 0-1, wyliczonym według metodyki EPPO 1/28 (3).
Uzyskane wyniki poddano ocenie statystycznej z zastosowaniem analizy wariancji, po uprzednim przekształceniu wyników według wzoru $\mathrm{y}=\arcsin \sqrt{\mathrm{x}}$. Istotność zróżnicowania wyników oceniono testem Fishera-Snedecora na poziomie istotności $\mathrm{p}=0,05$, natomiast badanie istotności różnic pomiędzy średnimi szacowano testem Tukeya.

\section{Wyniki i dyskusja / Results and discussion}

Rodzaj przedplonu miał istotny wpływ na stopień porażenia jęczmienia jarego przez grzyby rodzaju Fusarium spp. i Tapesya yallundae. Po przedplonie kukurydzy i uprawie płużnej porażenie roślin jęczmienia przez grzyby z rodzaju Fusarium spp. kształtowało się na poziomie $37,4 \%$, a w siewie bezpośrednim 42\% (tab. 1). Z kolei, gdy przedplonem były buraki średni procent roślin porażonych był mniejszy i wynosił odpowiednio $34,2 \%$ w uprawie tradycyjnej i $34,6 \%$ po siewie bezpośrednim. Porażenie jęczmienia uprawianego w zmianowaniu po buraku przez grzyb T. yallundae wynosił 3,3\%, a po kukurydzy 4,1\% (tab. 4). Sposób uprawy wpływał również na stopień porażenia roślin jęczmienia przez choroby podstawy źdźbła. Indeks porażenia jęczmienia jarego w doświadczeniu polowym był istotnie modyfikowany przez sposób uprawy w odniesieniu zarówno do fuzaryjnej zgorzeli podstawy źdźbła, jak i łamliwości źdźbła (tab. 3, 6). Najsłabszym porażeniem charakteryzował się jęczmień jary uprawiany na poletkach $\mathrm{z}$ siewem bezpośrednim. Oddziaływanie systemu regenerującego stanowisko, jakim był rodzaj pozostawionej biomasy utrzymywało się na podobnym poziomie. Nie odnotowano istotnych statystycznie różnic ani $\mathrm{w}$ procencie, ani $\mathrm{w}$ indeksie porażenia podstawy źdźbła i korzeni jęczmienia jarego po żadnym z pięciu rodzajów pozostawionej biomasy (tab. 5, 6). Wystapiła natomiast interakcja pomiędzy rodzajem pozostawionej biomasy a systemem uprawy w odniesieniu do fuzaryjnej zgorzeli podstawy źdźbła (tab. 3). Najwyższym indeksem porażenia podstawy źdźbła charakteryzowały się rośliny pochodzące $\mathrm{z}$ obiektów $\mathrm{z}$ tradycyjnym systemem uprawy roli $(0,21)$, na których pozostawiono biomasę wyki jarej. W odniesieniu do procentu roślin prażonych grzybem $T$. yalundae wystapiła interakcja przedplonu $\mathrm{z}$ rodzajem pozostawionej biomasy (tab. 4.) i sposobu uprawy roli z rodzajem pozostawionej biomasy (tab. 5). Największy odsetek źdźbeł z objawami choroby $(7,2 \%)$ obserwowano na obiektach $\mathrm{z}$ uprawą tradycyjną po pozostawieniu biomasy wyki jarej i przy pozostawieniu tej biomasy uprawianej po kukurydzy. Nie obserwowano natomiast takiej zależności w odniesieniu do indeksu nasilenia choroby (tab. 7,8).

Baturo (2007) w swoich badaniach wskazuje na zróżnicowany skład populacji grzybów zasiedlających podstawę źdźbła jęczmienia jarego. W systemie ekologicznym, w fazie początku krzewienia, izolowano liczniej Fusarium spp., jednak w fazie dojrzałości woskowej przeważającym patogenem był Botrytis sorokiniana, a Fusarium spp. stwierdzono głównie w systemie integrowanym i konwencjonalnym. Badania te wskazują na zmieniające się w czasie wzrostu roślin zagrożenia ze 
strony różnych patogenów. W badaniach własnych wykazano także wpływ przedplonu na nasilenie występowania chorób podsuszkowych. Silniej porażane były rośliny jęczmienia w uprawie po kukurydzy, niż po buraku cukrowym. Według Kurowskiego i wsp. (2005), mieszanka zbożowo-strączkowa i następstwo jęczmienia jarego po sobie bardziej niż ziemniak sprzyjają rozwojowi chorób podstawy źdźbła. Jedną $\mathrm{z}$ metod łagodzenia ujemnych skutków niekorzystnego następstwa roślin jest również uprawa międzyplonów (Andrzejewska 1999). Szczególnego znaczenia nabiera uprawa tych roślin na przyoranie, która poprawia jakość środowiska glebowego przy stosunkowo niewielkich nakładach (Duer 1996). W przeprowadzonych badaniach nie obserwowano jednak istotnego wpływu rodzaju pozostawionej biomasy na porażenie podstawy źdźbła i korzeni jęczmienia jarego.

Tabela 1. Procent porażenia roślin jęczmienia jarego przez grzyby z rodzaju Fusarium spp. w zależności od sposobu uprawy gleby i przedplonu

Table 1. Percentage of spring barley plants infected by Fusarium spp. depend on tillage system and forecrop

\begin{tabular}{|c|c|c|c|}
\hline \multirow{2}{*}{$\begin{array}{l}\text { Sposób uprawy roli } \\
\text { Tillage system }\end{array}$} & \multicolumn{2}{|c|}{ Przedplon - Forecrop } & \multirow{2}{*}{$\begin{array}{l}\text { Średnia } \\
\text { Mean }\end{array}$} \\
\hline & $\begin{array}{c}\text { burak } \\
\text { beet }\end{array}$ & $\begin{array}{c}\text { kukurydza } \\
\text { maize }\end{array}$ & \\
\hline Tradycyjna-Conventional & 34,2 & 42,0 & 38,1 \\
\hline Siew bezpośredni - Direct sowing & 34,6 & 37,4 & 36,0 \\
\hline Średnia - Mean & 34,4 & 39,7 & - \\
\hline $\begin{array}{l}\text { NIR }(0,05) \text { dla: } \\
\text { LSD }(0.05) \text { for: }\end{array}$ & \multicolumn{3}{|c|}{$\begin{array}{l}\text { A - sposobu uprawy - tillage system }- \text { r.n. } \\
B-\text { przedplonu - forecrop }-2,07 \\
\text { interakcji - interaction: A x B }-2,93\end{array}$} \\
\hline
\end{tabular}

r.n. - różnice nieistotne - not significant differences

Tabela 2. Procent porażenia roślin jęczmienia jarego przez grzyby z rodzaju Fusarium spp. w zależności od sposobu uprawy gleby i rodzaju pozostawionej biomasy

Table 2. Percentage of spring barley plants infected by Fusarium spp. depend on tillage system and kind of crop residue

\begin{tabular}{|c|c|c|c|c|c|c|}
\hline \multirow{2}{*}{$\begin{array}{l}\text { Sposób uprawy roli } \\
\text { Tillage system }\end{array}$} & \multicolumn{5}{|c|}{ Rodzaj pozostawionej biomasy - Kind of crop residue } & \multirow{2}{*}{$\begin{array}{c}\text { Średnia } \\
\text { Mean }\end{array}$} \\
\hline & $\begin{array}{l}\text { gorczyca biała } \\
\text { white mustard }\end{array}$ & $\begin{array}{c}\text { owies } \\
\text { oats }\end{array}$ & $\begin{array}{l}\text { wyka jara } \\
\text { spring vetch }\end{array}$ & $\begin{array}{l}\text { słoma pszenna } \\
\text { wheat straw }\end{array}$ & $\begin{array}{c}\text { kontrola } \\
\text { control }\end{array}$ & \\
\hline $\begin{array}{l}\text { Tradycyjna } \\
\text { Conventional }\end{array}$ & 41,5 & 36,5 & 40,5 & 34,0 & 38,0 & 38,1 \\
\hline $\begin{array}{l}\text { Siew bezpośredni } \\
\text { Direct sowing }\end{array}$ & 35,0 & 38,5 & 38,5 & 34,5 & 33,5 & 36,0 \\
\hline $\begin{array}{l}\text { Średnia } \\
\text { Mean }\end{array}$ & 38,2 & 37,5 & 39,5 & 34,2 & 35,7 & - \\
\hline $\begin{array}{l}\text { NIR }(0,05) \text { dla: } \\
\text { LSD }(0.05) \text { for: }\end{array}$ & \multicolumn{5}{|c|}{$\begin{array}{l}\text { A - sposobu uprawy - tillage system - r.n. } \\
C \text { - rodzaju pozostawionej biomasy - kind of crop residue }-3,42 \\
\text { interakcji - interaction: A x C - r.n. }\end{array}$} & \\
\hline
\end{tabular}

r.n. - różnice nieistotne - not significant differences

Tabela 3. Index porażenia roślin jęczmienia jarego przez Fusarium spp. w zależności od sposobu uprawy gleby i rodzaju pozostawionej biomasy

Table 3. Infection index of spring barley infected by Fusarium spp. depend on tillage system and kind of crop residue

\begin{tabular}{|c|c|c|c|c|c|c|}
\hline \multirow{2}{*}{$\begin{array}{l}\text { Sposób uprawy roli } \\
\text { Tillage system }\end{array}$} & \multicolumn{5}{|c|}{ Rodzaj pozostawionej biomasy - Kind of crop residue } & \multirow{2}{*}{$\begin{array}{l}\text { Średnia } \\
\text { Mean }\end{array}$} \\
\hline & $\begin{array}{l}\text { gorczyca biała } \\
\text { white mustard }\end{array}$ & $\begin{array}{l}\text { owies } \\
\text { oats }\end{array}$ & $\begin{array}{l}\text { wyka jara } \\
\text { spring vetch }\end{array}$ & $\begin{array}{l}\text { słoma pszenna } \\
\text { wheat straw }\end{array}$ & $\begin{array}{c}\text { kontrola } \\
\text { control }\end{array}$ & \\
\hline $\begin{array}{l}\text { Tradycyjna } \\
\text { Conventional }\end{array}$ & 0,20 & 0,16 & 0,21 & 0,18 & 0,20 & 0,19 \\
\hline $\begin{array}{l}\text { Siew bezpośredni } \\
\text { Direct sowing }\end{array}$ & 0,17 & 0,21 & 0,18 & 0,15 & 0,16 & 0,17 \\
\hline Średnia-Mean & 0,19 & 0,19 & 0,20 & 0,17 & 0,18 & - \\
\hline $\begin{array}{l}\text { NIR }(0,05) \text { dla: } \\
\operatorname{LSD}(0.05) \text { for: }\end{array}$ & \multicolumn{5}{|c|}{$\begin{array}{l}\text { A - sposobu uprawy - tillage system }-0,01 \\
\text { C - rodzaju pozostawionej biomasy - kind of crop residue - r.n. } \\
\text { interakcji - interaction: A x C }-0,041\end{array}$} & \\
\hline
\end{tabular}


Tabela 4. Procent porażenia roślin jęczmienia jarego przez T. yallundae w zależności od rodzaju pozostawionej biomasy i przedplonu Table 4. Percentage of spring barley plants infected by T. yallundae depend on kind of crop residue and forecrop

\begin{tabular}{|c|c|c|c|c|c|c|}
\hline \multirow{2}{*}{$\begin{array}{l}\text { Przedplon } \\
\text { Forecrop }\end{array}$} & \multicolumn{5}{|c|}{ Rodzaj pozostawionej biomasy - Kind of crop residue } & \multirow{2}{*}{$\begin{array}{c}\text { Średnia } \\
\text { Mean }\end{array}$} \\
\hline & $\begin{array}{l}\text { gorczyca biała } \\
\text { white mustard }\end{array}$ & $\begin{array}{c}\text { owies } \\
\text { oats }\end{array}$ & $\begin{array}{c}\text { wyka jara } \\
\text { spring vetch }\end{array}$ & $\begin{array}{l}\text { słoma pszenna } \\
\text { wheat straw }\end{array}$ & $\begin{array}{c}\text { kontrola } \\
\text { control }\end{array}$ & \\
\hline Burak-Beet & 3,1 & 2,7 & 2,5 & 4,1 & 4,2 & 3,3 \\
\hline Kukurydza - Maize & 3,2 & 5,0 & 7,2 & 2,7 & 2,7 & 4,1 \\
\hline Średnia - Mean & 3,2 & 3,9 & 4,9 & 3,4 & 3,4 & - \\
\hline $\begin{array}{l}\text { NIR }(0,05) \text { dla: } \\
\text { LSD }(0.05) \text { for: }\end{array}$ & \multicolumn{5}{|c|}{$\begin{array}{l}\mathrm{B} \text { - przedplonu - forecrop - r.n. } \\
\mathrm{C} \text { - rodzaju pozostawionej biomasy - kind of crop residue }- \text { r.n. } \\
\text { interakcji - interaction: } \mathrm{B} \text { x } \mathrm{C}-2,18\end{array}$} & \\
\hline
\end{tabular}

r.n. - różnice nieistotne - not significant differences

Tabela 5. Procent porażenia roślin jęczmienia jarego przez T. yallundae w zależności od sposobu uprawy gleby i rodzaju pozostawionej biomasy

Table 5. Percentage of spring barley plants infected by T. yallundae depend on tillage system and kind of crop residue

\begin{tabular}{|c|c|c|c|c|c|c|}
\hline \multirow{2}{*}{$\begin{array}{l}\text { Sposób uprawy roli } \\
\text { Tillage system }\end{array}$} & \multicolumn{5}{|c|}{ Rodzaj pozostawionej - Kind of crop residue } & \multirow{2}{*}{$\begin{array}{l}\text { Średnia } \\
\text { Mean }\end{array}$} \\
\hline & $\begin{array}{l}\text { gorczyca biała } \\
\text { white mustard }\end{array}$ & $\begin{array}{l}\text { owies } \\
\text { oats }\end{array}$ & $\begin{array}{l}\text { wyka jara } \\
\text { spring vetch }\end{array}$ & $\begin{array}{l}\text { słoma pszenna } \\
\text { wheat straw }\end{array}$ & $\begin{array}{l}\text { kontrola } \\
\text { control }\end{array}$ & \\
\hline $\begin{array}{l}\text { Tradycyjna } \\
\text { Conventional }\end{array}$ & 4,1 & 1,7 & 6,2 & 4,1 & 4,4 & 4,1 \\
\hline $\begin{array}{l}\text { Siew bezpośredni } \\
\text { Direct sowing }\end{array}$ & 2,2 & 6,0 & 3,5 & 2,7 & 2,2 & 3,3 \\
\hline Średnia - Mean & 3,2 & 3,9 & 4,9 & 3,4 & 3,3 & - \\
\hline $\begin{array}{l}\text { NIR }(0,05) \text { dla: } \\
\operatorname{LSD}(0.05) \text { for: }\end{array}$ & \multicolumn{5}{|c|}{$\begin{array}{l}\text { A - sposobu uprawy - tillage system }-0,69 \\
\mathrm{C} \text { - rodzaju pozostawionej biomasy - kind of crop residue }- \text { r.n. } \\
\text { interakcji - interaction: A x C }-2,18\end{array}$} & \\
\hline
\end{tabular}

r.n. - różnice nieistotne - not significant differences

Tabela 6. Index porażenia roślin jęczmienia jarego przez T. yallundae w zależności od sposobu uprawy gleby i przedplonu Table 6. Infection index of spring barley plants infected by T. yallundae depend on tillage system and forecrop

\begin{tabular}{|c|c|c|c|}
\hline \multirow{2}{*}{$\begin{array}{l}\text { Sposób uprawy roli } \\
\text { Tillage system }\end{array}$} & \multicolumn{2}{|c|}{ Przedplon - Forecrop } & \multirow{2}{*}{$\begin{array}{c}\text { Średnia } \\
\text { Mean }\end{array}$} \\
\hline & $\begin{array}{c}\text { burak } \\
\text { beet }\end{array}$ & $\begin{array}{c}\text { kukurydza } \\
\text { maize }\end{array}$ & \\
\hline Tradycyjna-Conventional & 0,011 & 0,022 & 0,017 \\
\hline Siew bezpośredni - Direct sowing & 0,014 & 0,021 & 0,018 \\
\hline Średnia - Mean & 0,013 & 0,022 & - \\
\hline $\begin{array}{l}\text { NIR }(0,05) \text { dla: } \\
\text { LSD }(0.05) \text { for: }\end{array}$ & \multicolumn{3}{|c|}{$\begin{array}{l}\text { A - sposobu uprawy - tillage system - r.n. } \\
\text { B - przedplonu - forecrop - r.n. } \\
\text { interakcji - interaction: A x B - r.n. }\end{array}$} \\
\hline
\end{tabular}

r.n. - różnice nieistotne - not significant differences

W doświadczeniu zastosowano także obiekt z przyorywaniem słomy. Steinbrenner i Höflich (1984) w badaniach nad porównaniem wpływu różnego nawożenia organicznego na porażenie przez patogeny podstawy źdźbła oraz produkcyjność jęczmienia jarego w warunkach Niemiec nie stwierdzili istotnych różnic tak w porażeniu, jak i plonowaniu tego zboża w zależności od przyorywania słomy. Podobne wnioski znajdziemy również w pracy Schönmeier i Rehbein (1988). Penn i Lynch (1982) nato- miast w swoich badaniach nad występowaniem grzybów z rodzaju Fusarium donoszą o zwiększonym ryzyku porażenia roślin przez te patogeny $\mathrm{w}$ związku $\mathrm{z}$ obecnością produktów fermentacji słomy. Wyniki badań własnych wskazują jednak, że presja ze strony patogenów roślin wywołujących choroby podsuszkowe była wyższa nie po przyoranej słomie, a po pozostawionej biomasie z wyki jarej czy gorczycy. 
Tabela 7. Index porażenia roślin jęczmienia jarego przez T. yallundae w zależności od sposobu uprawy gleby i rodzaju pozostawionej biomasy

Table 7. Infection index of spring barley plants infected by T. yallundae depend on tillage system and kind of crop residue

\begin{tabular}{|c|c|c|c|c|c|c|}
\hline \multirow{2}{*}{$\begin{array}{l}\text { Sposób uprawy roli } \\
\text { Tillage system }\end{array}$} & \multicolumn{5}{|c|}{ Rodzaj pozostawionej biomasy - Kind of crop residue } & \multirow{2}{*}{$\begin{array}{l}\text { Średnia } \\
\text { Mean }\end{array}$} \\
\hline & $\begin{array}{l}\text { gorczyca biała } \\
\text { white mustard }\end{array}$ & $\begin{array}{c}\text { owies } \\
\text { oats }\end{array}$ & $\begin{array}{l}\text { wyka jara } \\
\text { spring vetch }\end{array}$ & $\begin{array}{l}\text { słoma pszenna } \\
\text { wheat straw }\end{array}$ & $\begin{array}{c}\text { kontrola } \\
\text { control }\end{array}$ & \\
\hline $\begin{array}{l}\text { Tradycyjna } \\
\text { Conventional }\end{array}$ & 0,015 & 0,005 & 0,021 & 0,013 & 0,030 & 0,017 \\
\hline $\begin{array}{l}\text { Siew bezpośredni } \\
\text { Direct sowing }\end{array}$ & 0,007 & 0,021 & 0,014 & 0,035 & 0,010 & 0,018 \\
\hline Średnia - Mean & 0,011 & 0,013 & 0,018 & 0,024 & 0,020 & - \\
\hline $\begin{array}{l}\text { NIR }(0,05) \text { dla: } \\
\text { LSD }(0.05) \text { for: }\end{array}$ & \multicolumn{5}{|c|}{$\begin{array}{l}\mathrm{A} \text { - sposobu uprawy - tillage system - r.n. } \\
\mathrm{C} \text { - rodzaju pozostawionej biomasy - kind of crop residue - r.n. } \\
\text { interakcji - interaction: A x C - r.n. }\end{array}$} & \\
\hline
\end{tabular}

r.n. - różnice nieistotne - not significant differences

Tabela 8. Index porażenia roślin jęczmienia jarego przez T. yallundae w zależności od przedplonu i rodzaju pozostawionej biomasy Table 8. Infection index of spring barley plants infected by T. yallundae depend on forecrop and kind of crop residue

\begin{tabular}{|c|c|c|c|c|c|c|}
\hline \multirow{2}{*}{$\begin{array}{l}\text { Przedplon } \\
\text { Forecrop }\end{array}$} & \multicolumn{5}{|c|}{ Rodzaj pozostawionej biomasy - Kind of crop residue } & \multirow{2}{*}{$\begin{array}{c}\text { Średnia } \\
\text { Mean }\end{array}$} \\
\hline & $\begin{array}{l}\text { gorczyca biała } \\
\text { white mustard }\end{array}$ & $\begin{array}{l}\text { owies } \\
\text { oats }\end{array}$ & $\begin{array}{l}\text { wyka jara } \\
\text { spring vetch }\end{array}$ & $\begin{array}{l}\text { słoma pszenna } \\
\text { wheat straw }\end{array}$ & $\begin{array}{c}\text { kontrola } \\
\text { control }\end{array}$ & \\
\hline Burak-Beet & 0,012 & 0,012 & 0,007 & 0,016 & 0,015 & 0,013 \\
\hline Kukurydza - Maize & 0,010 & 0,014 & 0,028 & 0,032 & 0,025 & 0,022 \\
\hline Średnia - Mean & 0,011 & 0,013 & 0,018 & 0,024 & 0,020 & - \\
\hline $\begin{array}{l}\text { NIR }(0,05) \text { dla: } \\
\text { LSD }(0.05) \text { for: }\end{array}$ & \multicolumn{5}{|c|}{$\begin{array}{l}\mathrm{B} \text { - przedplonu - forecrop - r.n. } \\
\mathrm{C} \text { - rodzaju pozostawionej biomasy - kind of crop residue - r.n. } \\
\text { interakcji - interaction: } \mathrm{B} \text { x C - r.n. }\end{array}$} & \\
\hline
\end{tabular}

r.n. - różnice nieistotne - not significant differences

Uprawa międzyplonów na przyoranie jest prekursorem trwałej materii organicznej, pomaga w rozwoju mikroorganizmów glebowych oraz wpływa na fizykochemiczne właściwości gleby (Malicki i Michałowski 1994). Stały dopływ substancji organicznej do gleby w postaci międzyplonu pozwala zachować jej aktywność biologiczna, co prowadzi do poprawy jej stanu fitosanitarnego (Kuś i wsp. 1993).

\section{Wnioski / Conclusions}

1. Przeprowadzone badania wykazały, że rodzaj przedplonu pod uprawę jęczmienia jarego miał istotny wpływ na stopień porażenia roślin jęczmienia jarego przez grzyby z rodzaju Fusarium spp. i T. yallundae. Jęczmień uprawiany po kukurydzy wykazywał uszkodzenia na poziomie powyżej $25 \%$, natomiast po burakach pastewnych średni procent porażonych roślin był mniejszy.

2. Sposób uprawy gleby istotnie różnicował stopień porażenia roślin jęczmienia przez sprawców fuzaryjnej zgorzeli podstawy źdźbła. Większe nasilenie choroby obserwowano na poletkach $\mathrm{z}$ plużną uprawą gleby, natomiast siew bezpośredni ograniczał jej występowanie. Podobnie w przypadku łamliwości podstawy źdźbła, obiekty z siewem bezpośrednim charakteryzowały się mniejszym porażeniem.

\section{Literatura / References}

Andrzejewska J. 1999. Międzyplony w zmianowaniach zbożowych. Post. Nauk Rol. 1: 19-31.

Baturo A. 2007. Effect of organic system on spring barley stem base health in comparison with integrated and conventional farming. J. Plant Prot. Res. 47 (2): 167-178.

Duer I. 1996. Mulczujący wpływ międzyplonu na plonowanie jęczmienia jarego oraz zawartość wody i azotanów w glebie. Fragm. Agron. 1 (49): 29-43.

Dzienia S., Boligłowa E. 1993. Rola mulczowania w podnoszeniu żyzności i urodzajności gleby. Post. Nauk Rol. 1: 107-111.

Kotwica K., Jaskulski D., Tomalak S. 1998. Wpływ przyorywania masy roślinnej i zróżnicowanej uprawy roli na plon jęczmienia jarego wysiewanego po pszenicy ozimej. Pam. Puł. 112: 105-113. 
Kurowski T.P., Wanic M., Nowicki M., Kostrzewska M., Sargalski D. 2005. Fitosanitarna ocena mieszanki zbożowo-strączkowej jako przedplonu dla jęczmienia jarego. Acta Sci. Pol., Agricultura 4 (1): 61-68.

Kuś J., Siuta A., Mróz A., Kamińska M. 1993. Możliwość kompensacji ujemnego wpływu stanowiska na plonowanie jęczmienia jarego. Pam. Puł. 103: 133-143.

Malicki L., Michałowski C. 1994. Problem międzyplonów w świetle doświadczeń. Post. Nauk Rol. 4: 4-18.

Parylak D. 2004. Possibilities of root and steam base diseases limitation in continuous wheat under conventional tillage and no-tillage system. J. Plant Prot. Res. 44 (2): 141-146.

Pecio A., Danyte V. 2008. Wpływ warunków pogody na porażenie zbóż jarych patogenami liści i kłosów. Prog. Plant Prot./Post. Ochr. Roślin 48 (2): 499-503.

Penn S.J., Lynch J.M. 1982. The effect of bacterial fermentation of couch grass rhizomes and Fusarium culmorum on the growth of barley seedlings. Plant Pathol. 31: 39-43.

Richards I., Wallace P., Turner I. 1996. A comparison of six cover crop types in terms of nitrogen uptake and effect on response to nitrogen by a subsequent spring barley crop. J. Agric. Sci. Camb. 127: 441-449.

Schönmeier H., Rehbein G. 1988. Zur Strohdüngung bei unterschiedlicher Getreidekonzentration auf Sandlöß-Braunschwarzerde. Arch. Acker-Pflanzenbau Bodenkd. 32 (10): 659-665.

Steinbrenner K., Höflich G. 1984. Einfluss acker- und pflanzenbaulicher Maßnahmen auf den Befall des Getreides durch Pseudocercosporella herpotrichoides (Fron) Deighton und Gaeumannomyces graminis (Sacc.) Arx et Olivier. Arch. Phytopathol. Pflanzenschutz 20 (6): 469-486.

Wojciechowski W. 2005. Oddziaływanie przyorywanych międzyplonów ścierniskowych i nawożenia azotem na zdrowotność roślin pszenicy jakościowej. Prog. Plant Prot./Post. Ochr. Roślin 45 (2): 1197-1200. 